\title{
触 New Disease Reports \\ New record of bipartite Squash leaf curl China virus (SLCCNV) and Croton yellow vein mosaic beta satellite associated with yellow vein disease of ash gourd in India
}

\author{
S.U. Mohammed Riyaz, S. Deepan, M.I. Jesse, G. Dharanivasan and K. Kathiravan
}

Plant Molecular Virology and Nanobiotechnology Laboratory, Department of Biotechnology, University of Madras, Guindy Campus, Chennai 600025, India

*E-mail: drkkathiravan@gmail.com

Received: 11 Dec 2014. Published: 01 Feb 2015. Keywords: begomovirus, viral plant disease

Benincasa hispida commonly known as winter melon or ash gourd is the only member of its genus belonging to the family Cucurbitaceae. It is one of the most commercially important vegetable crops cultivated in the Indian subcontinent, especially in the state of Tamil Nadu, where leaf curl disease of this plant has become a serious problem recently. Infected leaf samples were collected from the field, virions were partially purified (Honda et al., 1983) and confirmed using HR-TEM (Fig. 1). Rolling circle amplification (RCA) (TempliPhi kit, GE healthcare, UK) was carried out and was followed with BamHI and HindIII restriction digestions. The amplified DNA-A fragments (2739 nt, GenBank Accession No. KF188433) consisted of 8 open reading frames (ORFs), whereas the amplified DNA-B (2683 nt, KJ004521) had two ORFs. Both DNA-A and DNA-B components were cloned and sequenced. The sequence data revealed $98 \%$ sequence identity to DNA-A (AY184487) and 93\% sequence identity to DNA-B (AY184488) components of SLCCNV-India [India: Coimbatore: Pumpkin]. The $\beta$-satellite component ( 1.3 kb) was amplified by PCR (Fig. 2) using specific primers (Briddon et al., 2003) and the sequence (KM588256) was found to be $88 \%$ identical to CYVMV leaf curl $\beta \mathrm{C} 1$ strain.

A phylogenetic tree was drawn using the neighbour-joining method (MEGA version 6; Tamura et al., 2011) with a bootstrap value of 1000 replicates. DNA- $\beta$ of CYVMV from B. hispida plants collected from the Perambalur district of Tamil Nadu was placed in an outlying group in this phylogram (Fig. 3). This is the first report from India on the incidence of old world bipartite Begomovirus SLCCNV-IN KP1 infection in combination with DNA- $\beta$ of CYVMV in B. hispida. The frequency of new SLCCNV strains emerging in several agricultural crops and non-crop species indicate that the virus species may have undergone pathogen reassortment with diverse virulent strains as a long-term event and thus pose a serious threat to vegetable cultivation, particularly in the Indian subcontinent.

\section{References}

Briddon RW, Bull SE, Amin I, Idris AM, Mansoor S, Bedford ID, Dhawan P, Rishi N, Siwatch SS, Abdel-Salam AM, Brown JK, Zafar, Y, Markham PG, 2003. Diversity of DNA $\beta$, a satellite molecule associated with some monopartite begomoviruses. Virology 312, 106-121.

http://dx.doi.org/10.1016/S0042-6822(03)00200-9

Honda Y, Iwaki M, Saito Y. Thongmeearkom P, Kittisak K, Demma N, 1983. Mechanical transmission, purification and some properties of whitefly-borne mungbean yellow mosaic virus in Thailand. Plant Disease 67, 801-804. http://dx.doi.org/10.1093/molbev/msr121

Tamura K, Peterson D, Peterson N, Stecher G, Nei M, Kumar S, 2011. MEGA5: Molecular evolutionary genetics analysis using maximum likelihood, evolutionary distance, and maximum parsimony methods. Molecular Biology and Evolution 28, 2731-2739.

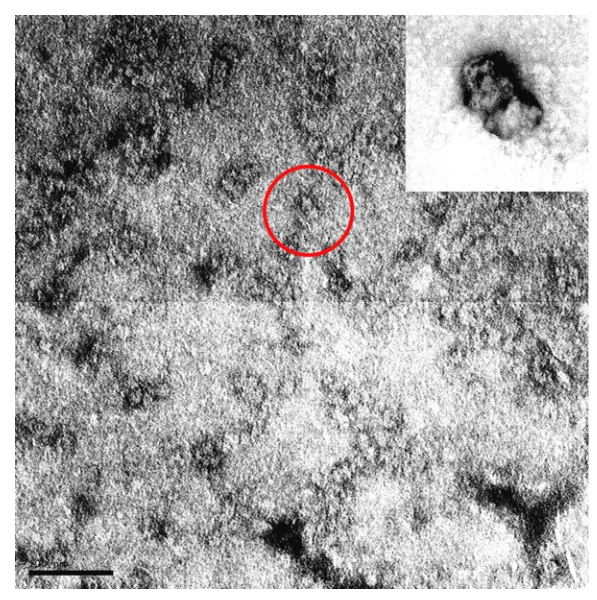

Figure 1
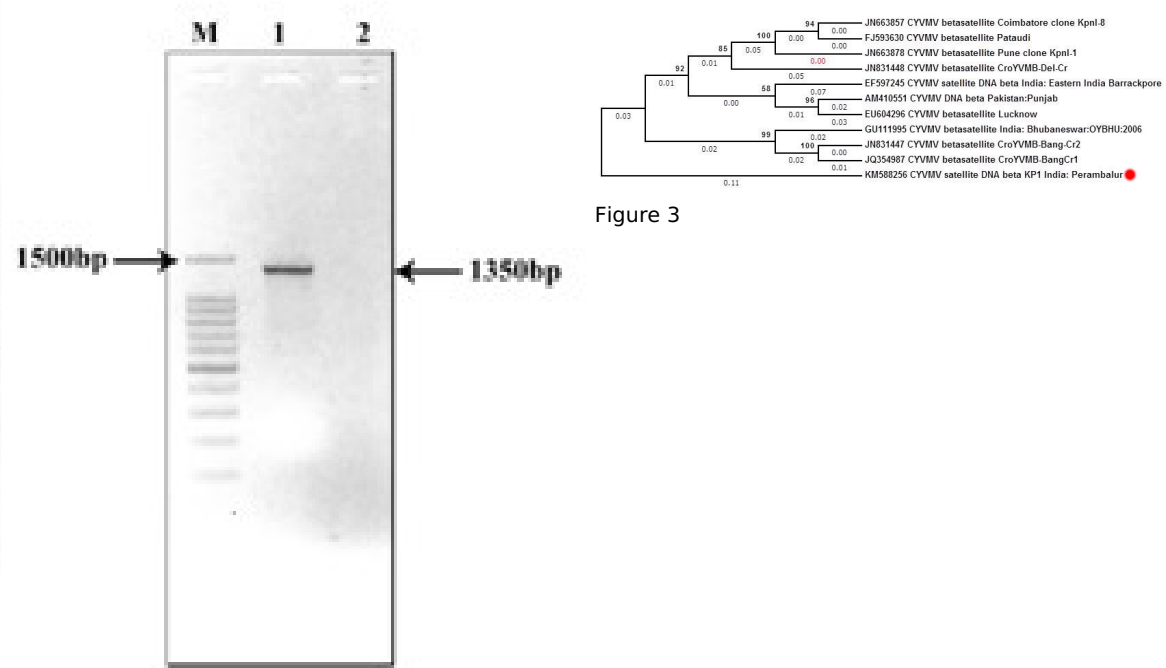

Figure 3

Figure 2

To cite this report: Mohammed Riyaz SU, Deepan S, Jesse MI, Dharanivasan G, Kathiravan K, 2015. New record of bipartite Squash leaf curl China virus (SLCCNV) and Croton yellow vein mosaic beta satellite associated with yellow vein disease of ash gourd in India. New Disease Reports 31, 3. http://dx.doi.org/10.5197/j.2044-0588.2015.031.003 